\title{
MUSCULAR CHANGES IN RHEUMATOID ARTHRITIS
}

\author{
BY \\ D. A. H. YATES* \\ From the Department of Medicine, Hammersmith Hospital, London
}

Atrophy and weakness of the limb muscles are extremely common in rheumatoid arthritis, the most likely causes being inhibition and disuse as a result of painful movement. However, other factors which may contribute are neurogenic atrophy as a result of a diffuse or localized neuropathy, direct extension of inflammatory tissue from neighbouring joints, or polymyositis arising as a manifestation of the systemic disease.

Round cell nodular infiltrations of muscle have been recorded in approximately 50 per cent. of cases of rheumatoid arthritis. Although initially this appearance was claimed by Steiner, Freund, Leichtentritt, and Maun (1946) to be a specific change, this was later refuted by Sokoloff, Wilens, and Bunim (1951), who showed similar but less florid changes in 25 per cent. of non-rheumatoid subjects.

Electromyographic studies in rheumatoid arthritis have produced conflicting reports. Thus Morrison, Short, Ludwig, and Schwab (1947) detected involuntary activity in muscles related to involved joints, but Mueller and Mead (1952) found this could invariably be stopped by careful positioning of the joints. Steinberg and Parry (1961) found changes which they claimed were indicative of polymyositis in 85 per cent. of 93 cases though they have no details of any objective measurements of volitional activity. Graudal and Hvid (1959) and Moritz (1961) found shortening of the mean potential duration (M.P.D.) in the small muscles of the hand in about 60 per cent. of cases with hand involvement which they thought indicated a myopathic process, whereas Amick (1960) in a similar study found no such changes.

The present study was undertaken to clarify the conflict between these earlier reports. It was thought that the clinical and electromyographic characteristics of individual muscles should be correlated with the condition of underlying joints

* Present address: St. Thomas's Hospital, London, S.E.1. and with the histological appearance of biopsy material. The deltoid muscle was considered the most suitable for detailed investigation as it has only one belly, spans a single joint, and is a suitable muscle for drill biopsy, and myopathic involvement is more marked in proximal muscles.

In Great Britain the main electrodiagnostic criterion of a myopathy has been the detection of a qualitative change in the electrical activity produced on volition. Individual potentials are smaller in amplitude and shorter in duration and a higher proportion are polyphasic. This increases the high frequency component in the electrical activit produced on volition, and this change can be detected audibly on a loudspeaker, by electronire frequency analysis, or by measuring the duration of individual potentials. Preliminary experiments using a frequency analyser in known myopathic patients gave conflicting results which were difficult to quantitate or grade as in the same muscle some areas produced a typical myopathic pattern while others produced a normal pattern. To complicate matters further, seemingly "myopathic" areas were found in normal controls. Buchthal and Pinelli (1953) have shown that, in myopathic muscle, the mean duration of a number of individual potentials is significantly shorter than in the normal, and this result is quantitative allowing serial readings to be compared. Occasionally myopathic muscles show the changes of denervation, namely abnormal intensity-duration relationships on direct stimulation and fibrillation potentials at rest (Richardson, 1956). Therefore it was decided to perform a routine electromyogram (E.M.G.) on the deltoid and quadriceps in each case and to estimate the M.P.D. in the deltoid for correlation with the biopsy findings.

\section{Clinical Assessment}

\section{Methods}

34 cases were studied which all satisfied the American Rheumatism Association criteria (Ropes, Bennett, 
Cobb, Jacox, and Jessar, 1959) of classical rheumatoid arthritis and in all the disease was active. The general activity of the disease, the functional grade, the pattern of joint involvement, and any evidence of neuropathy were assessed in each case.

Both shoulders and both knees were examined in detail, the range and pain of passive movements being noted. The power of resisted abduction of the shoulders and extension of the knees was estimated to be either normal, moderately weak, severely weak, or absent. $X$ rays of the shoulders and knees were examined, the degree of erosive change, osteoporosis, and diminution of joint space being noted. If there was asymmetrical involvement of the shoulders and knees, the deltoid and quadriceps on the more affected side were studied providing the joints were not clinically ankylosed.

\section{Electrodiagnosis}

Bauwens (1962) has described the routine tests for detection of denervation in muscle. These consist of the determination of the intensity-duration (I-D) ratio on direct stimulation and, with intramuscular electrodes, the detection of denervation potentials at rest followed by a study of the electrical activity produced on volition. These tests were applied to the deltoid and quadriceps in every case.

The M.P.D. in the deltoid was obtained by a modification of the technique described by Buchthal, Guld, and Rosenfalck (1954). Using intramuscular needle electrodes and recording on a two-channel cathode ray oscilloscope, approximately twenty different action potentials from various depths of the muscle were photographed at minimal volition. The total duration in milliseconds of each potential was measured on the film and then the mean duration of all the potentials was calculated (Yates, 1963).

\section{Biopsy}

In 23 cases a biopsy was taken from the same muscle at a site just below that used for the E.M.G. within a few minutes of completing it. A horizontal track right through the muscle and the overlying shin were infiltrated with a small amount of 2 per cent. lignocaine (pH 6.8 and made isotonic with $\mathrm{NaCl}$ ). A small vertical incision was made through the skin and the subcutaneous fat was separated by blunt dissection down to the muscle. A sharpened cannula $5 \mathrm{~cm}$. long with an internal diameter of $2 \mathrm{~mm}$. was mounted on the chuck of a Down Bros. turbine drill driven by compressed air (Deeley, 1960). The cannula, rotating at approximately 18,000 revolutions per minute, was gently pushed through the deltoid, at right angles to the humerus, to the subcutaneous fat on the opposite side. Then with gentle suction from a syringe the cannula containing a core of muscle was withdrawn. The specimen was fixed in formol mercury having been allowed to adhere to a matchstick to prevent gross shrinkage. For microscopy the specimen was cut longitudinally at three different levels and stained with haematoxylin and eosin.

Firm pressure over the biopsy site produced adequate haemostasis and the skin incision was closed with three butterfly plasters. Adequate samples were obtained with ease at every attempt and no complications were encountered.

\section{Results \\ Routine Electrodiagnosis}

No evidence of denervation was found in the deltoid or quadriceps of any of the cases studied, that is, the I-D ratios were normal and fibrillation potentials were not detected. The majority of cases who had an active arthritis of the knee or shoulder at the time of the examination or had quiescent but damaged joints could not produce a normal interference pattern on full volition. It was apparent that the number of motor units that could be activated was reduced, either by pain inhibition or prolonged disuse, but this change was quite non-specific.

\section{Mean Potential Duration Studies}

Controls.-The normal range of M.P.D. in the deltoid for the particular equipment used was established by studying 28 control subjects with ages ranging from 20 to 80 years who showed no evidence of neuro-muscular disease (Fig. 1).

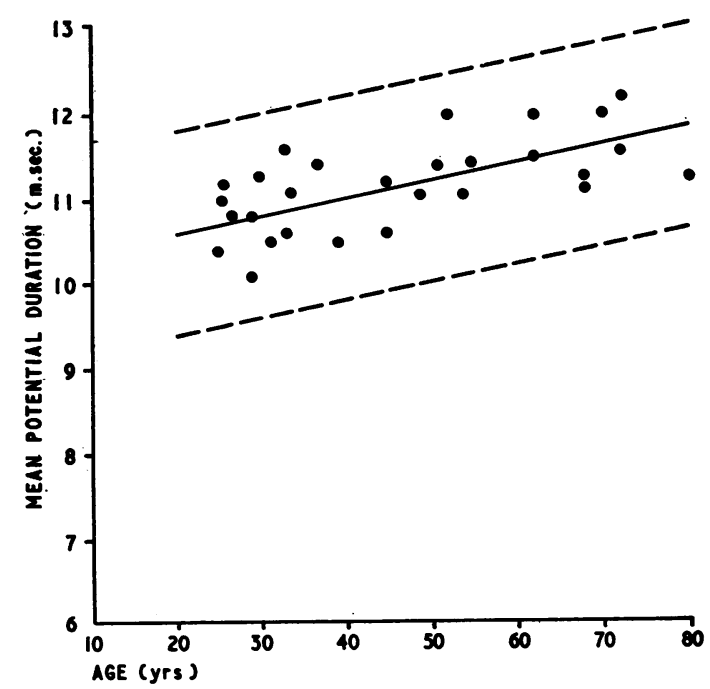

Fig. 1.-Relation between age (yrs) and mean potential duration (M.P.D.) in 28 control subjects.

Equation of regression line is: M.P.D. $=0.020 \times$ Age +10.21 . Broken lines are three standard deviations $(3 \times 0.40 \mathrm{msec} .=1.20$ msec.) either side of the regression line; these are taken as the normal limits. 
There is a gradual increase in M.P.D. with age (correlation coefficient $=0.64 ; \mathrm{P}<0.01$ ). The normal range was taken to be three standard deviations either side of the regression line. Muscles with an M.P.D. shorter than the lower limit could be considered as myopathic. To check the validity of this assumption, sixteen cases with a definite myopathy were studied: eight cases of thyrotoxic myopathy, three of Cushing's syndrome with myopathy, three of muscular dystrophy, and two of polymyositis. Fig. 2 shows the M.P.D. to be considerably shorter than the normal range in all cases. Repeat estimations in the same subject and "blind" readings of records agreed within 5 per cent. of the original estimations.

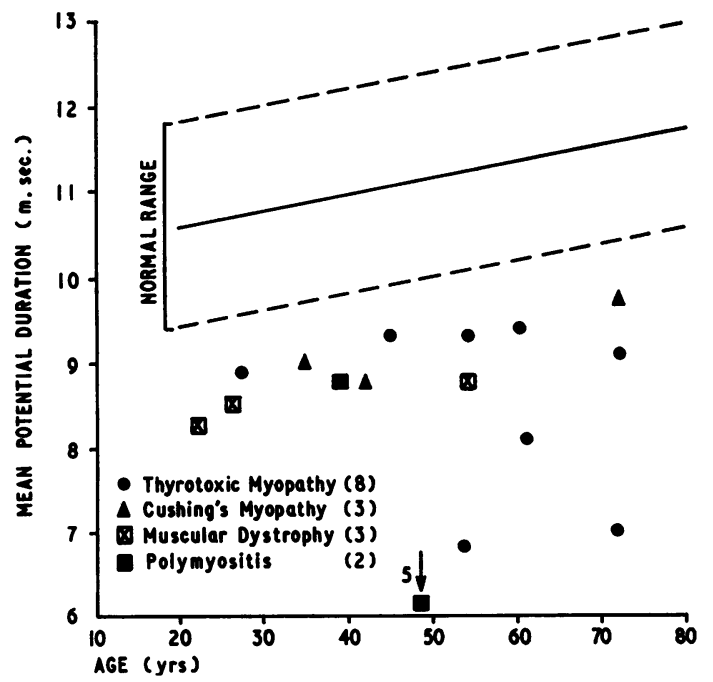

Fig. 2.-Mean potential duration in deltoid muscle of sixteen cases of myopathy.

Rheumatoid Arthritis.-The findings in the 34 cases are shown in Fig. 3. In eighteen of twenty cases not receiving steroid treatment, the M.P.D. in the deltoid was within the normal range. Two cases showed significant shortening of the M.P.D. and both of these had coincident thyrotoxicosis proven by radioactive iodine excretion tests (and in one by thyroid biopsy). In contrast, ten of seventeen cases receiving corticosteroid therapy showed significant shortening of the M.P.D. into the myopathic range. Three cases were studied before starting steroid therapy and two of these developed a myopathic change after treatment for 3 months.

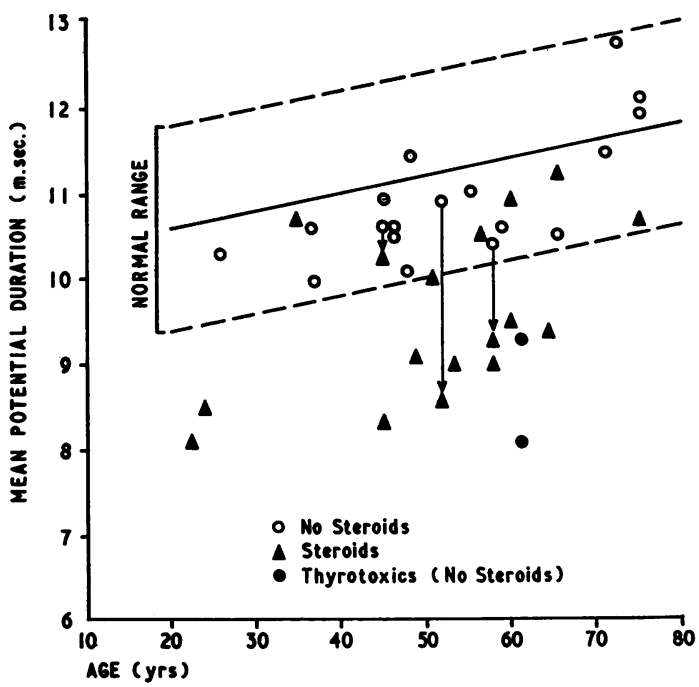

Fig. 3.-Mean potential duration in deltoid muscle in 34 cases of rheumatoid arthritis. Downward-pointing arrows indicate change after 3 months' steroid therapy.

On comparison of those cases who were receiving steroid therapy with those who were not, little difference in the mean age, duration of disease, of functional grade is seen in the two groups and although there is a slightly greater proportion cases with a positive Waaler-Rose (D.A.T.) tes among the steroid-treated cases, the difference is probably of no significance (Table I).

TABLE I

COMPARISON OF THERAPY RECEIVED BY RHEUMATOID CASES

\begin{tabular}{|c|c|c|c|c|c|c|}
\hline \multirow{2}{*}{ Therapy } & \multirow{2}{*}{$\begin{array}{c}\text { No. } \\
\text { of } \\
\text { Cases }\end{array}$} & \multirow{2}{*}{$\begin{array}{c}\text { Mean } \\
\text { Age } \\
\text { (yrs) }\end{array}$} & \multirow{2}{*}{$\begin{array}{c}\text { Mean } \\
\text { Duration } \\
\text { of } \\
\text { Disease } \\
\text { (yrs) }\end{array}$} & \multirow{2}{*}{$\begin{array}{c}\text { Mean } \\
\text { Functional } \\
\text { Grade }\end{array}$} & \multicolumn{2}{|c|}{$\underset{\text { Positive }}{\text { D.A.T. }}$} \\
\hline & & & & & No. & $\begin{array}{c}\text { Per } \\
\text { cent. }\end{array}$ \\
\hline No Steroids & 18 & 53 & 7 & 3 & 12 & 66 \\
\hline Steroids & 17 & 51 & 9 & 3 & 14 & 82 \\
\hline All Cases . . & 32 & 52 & 8 & 3 & 23 & 72 \\
\hline
\end{tabular}

When the steroid-treated cases are considered, $\tilde{N}$ little difference can be shown between those in $\underset{\omega}{N}$ which the M.P.D. was found to be normal and those in whom it was in the myopathic range (Table II, co opposite).

The mean age, duration of disease, and steroid $\stackrel{\oplus}{?}$ therapy, and the proportion of sero-positive cases 
show little difference. One case in the series with a short M.P.D. receiving large doses of prednisone for a mononeuritis multiplex was not included in this analysis, but in the remainder the mean dose of steroid (expressed as prednisone equivalent) was slightly higher in the cases with a short M.P.D. although the range of dosage is similar. Many of the steroid preparations in common use, including corticotrophin, produced this effect.

TABLE II

M.P.D. OF CASES ON STEROID THERAPY

\begin{tabular}{|c|c|c|}
\hline $\begin{array}{lll}\text { M.P.D. } & \text {.. }\end{array}$ & Normal & Short \\
\hline No. of Cases.. & 7 & 9* \\
\hline Mean Age (yrs) & 55 & 48 \\
\hline $\begin{array}{cc}\begin{array}{c}\text { Mean Duration } \\
\text { Disease }(\mathrm{yrs})\end{array} \\
\end{array}$ & 10 & 10 \\
\hline 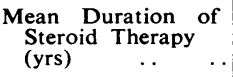 & 4 & 4 \\
\hline D.A.T. Positive & $\begin{array}{c}6 \\
\text { (85 per cent.) }\end{array}$ & $\begin{array}{c}{ }^{7} \\
\text { (77 per cent.) }\end{array}$ \\
\hline $\begin{array}{l}\text { Mean Dosage of Oral } \\
\text { Steroid (Prednisone } \\
\text { equivalent) (mg.) } . .\end{array}$ & $\begin{array}{c}13 \\
\text { (range 4-23) }\end{array}$ & $\begin{array}{c}15 \\
\text { (range 8-20) }\end{array}$ \\
\hline Type of Steroid Given & $\begin{array}{l}5 \text { Prednisone } \\
1 \text { Methyl- } \\
\text { prednisolone } \\
1 \text { Triamcinolone }\end{array}$ & $\begin{array}{l}3 \text { Prednisone } \\
2 \text { Methyl- } \\
\text { prednisolone } \\
1 \text { Betamethasone } \\
1 \text { Triamcinolone } \\
2 \text { ACTH }\end{array}$ \\
\hline
\end{tabular}

* One case on $70-100 \mathrm{mg}$. prednisone for 3 months is excluded from this Table.

The majority of the cases on corticosteroids with a short M.P.D. showed some weakness of the deltoid but usually the shoulder joint was arthritic. However, in two cases, there was marked weakness and wasting of the deltoid without any clinical or radiological evidence of involvement of the shoulder joint, this being the clinical picture of a myopathy.

In six cases there was evidence of a peripheral neuropathy; this took the form of a mild symmetrical peripheral motoro-sensory neuropathy in three, an asymmetrical mononeuritis multiplex in one, and a unilateral carpal tunnel syndrome in one. In none of these cases were signs of denervation found in the deltoid or quadriceps, indicating that the proximal musculature was not affected by the neuropathy.

\section{Biopsy Results}

Definite nodular myositis was found in fourteen of 23 (60 per cent.) biopsies. The changes were present in nine of thirteen (70 per cent.) cases not on corticosteroids, and in five of ten (50 per cent.) cases on corticosteroids: thus there was no correlation of these changes with the E.M.G. findings. In both groups nodular myositis was detected more frequently in sero-positive than in sero-negative cases, but in no case was the histological picture of polymyositis encountered. Apart from one case in which a single arteritic lesion was found, the intramuscular arteries were normal.

\section{Discussion}

Polymyositis is not a single disease entity but can be regarded as a clinical syndrome which may complicate a variety of diseases ranging from virus infection to carcinomatosis. The main feature of the syndrome is a diffuse, degenerative condition of muscle, involving particularly the trunk, face, and proximal limb muscles. This syndrome can certainly appear as a complication of rheumatoid arthritis, and Walton and Adams (1958) have reported four such cases: two of these patients deteriorated and died of intercurrent disease, while the other two showed some spontaneous improvement. Since this complication will markedly increase the disability from the arthritis and since it can often be reversed or arrested by corticosteroid therapy, the accurate detection of polymyositis is of more than academic interest. The failure to find electrodiagnostic or histological evidence of a diffuse polymyositis in eighteen cases of uncomplicated rheumatoid arthritis suggests that this is a rare complication.

The detection of E.M.G. evidence of myopathy in more than half the cases on corticosteroid therapy was unexpected. However, there is considerable evidence that an excess of circulating cortisol or one of its derivatives may cause myopathy. In animal experiments, muscle necrosis has been reported by Ellis (1956) in cortisone-fed rats and by Kendall (1960) in dexamethasone-fed rats. In Cushing's syndrome muscle weakness was described by Cushing (1932) and myopathy by Müller and Kugelberg (1959). Myopathy complicating therapy with a variety of synthetic corticosteroids has been reported, including cortisone (Perkoff, Silber, Tyler, Cartwright, and Wintrobe, 1959), prednisone (Harman, 1959), triamcinolone (Kendall and Hart, 1959), fludrocortisone (MacLean and Schurr, 1959), and dexamethasone (Golding, Murray, Pearce, and Thompson, 1961). The results of the present study indicate that the electrical changes characteristic of a myopathy occur more frequently and at a lower dosage of corticosteroids than has previously been 
recognized. It also appears that corticotrophin should be added to the list of agents that can cause myopathy. However, since some of the electrophysiological factors which determine the duration of potentials recorded in muscle are unknown, these results must be interpreted with caution. Further investigation is required to draw valid conclusions as to the critical dosage level and duration of treatment to produce these effects, but it would appear that some individuals are more prone than others.

The insertion of needle electrodes produces a localized traumatic myositis within 24 hours (Woolf, 1962), and the drill biopsy technique was devised to obtain a histological sample immediately following the E.M.G. before these traumatic artefacts could occur. It was found suitable for use on outpatients since no pre-medication or suturing was necessary and full operating theatre facilities were not required.

The features of nodular myositis were described in detail by Steiner and others (1946). Collections of lymphocytes and plasma cells occur between muscle fibres and in the intramuscular connective tissue, often in relation to blood vessels (Fig. 4).

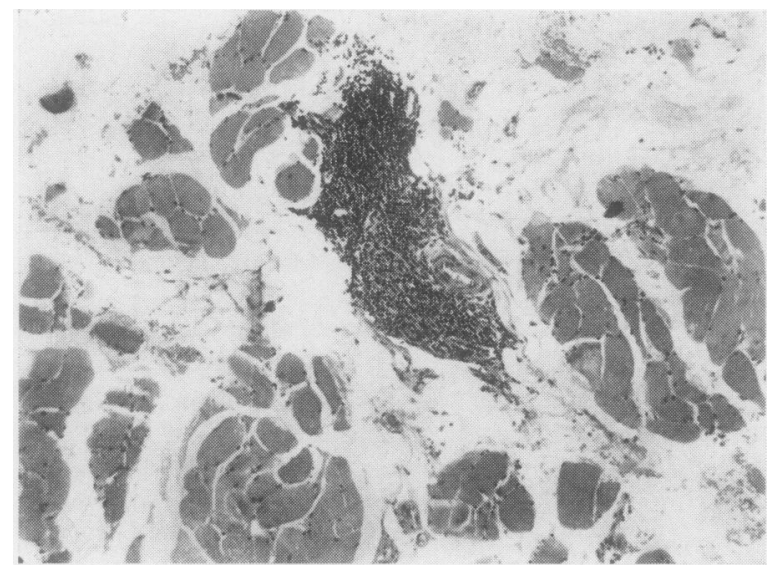

Fig. 4.-Drill biopsy of deltoid muscle from a case of rheumatoid arthritis, showing collection of chronic inflammatory cells around a normal arteriole. $\times 66$.

Occasionally a few degenerating or regenerating muscle fibres can be discerned at the edge of the nodules (Fig. 5), but the remaining fibres look normal. This is in contrast to the appearance of polymyositis where diffuse infiltration with chronic inflammatory cells and diffuse degeneration of muscle fibres are seen. Nodular myositis was detected in 60 per cent. of cases, a similar figure to that given in previous studies in which much more extensive sampling was performed, indicating that the drill technique described here provides an adequate biopsy sample.

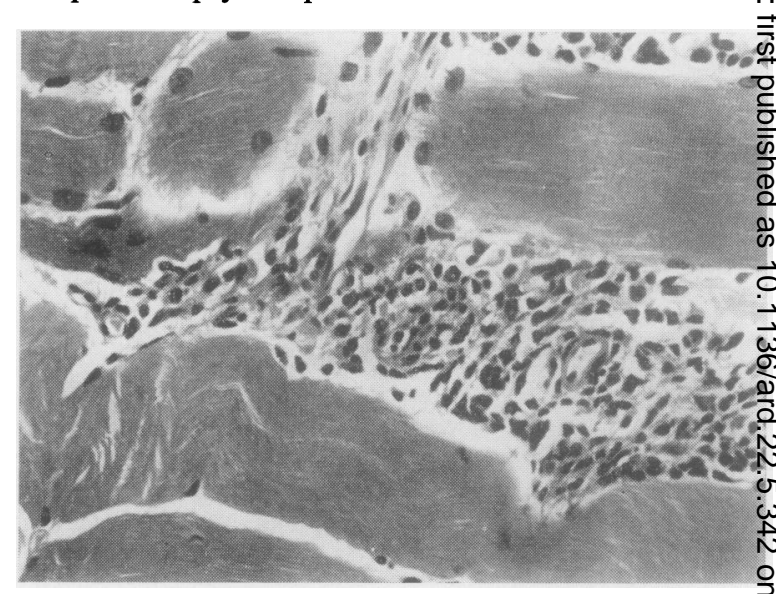

Fig. 5.-Nodular myositis in deltoid muscle in a case of rheumatoid arthritis. Note dark-staining regenerating muscle fibre at left edge of nidus, but other fibres are normal. $\times 246$.

The absence of specific histological changes in the muscles in which the M.P.D. was short is in keeping with some other reports of conventional muscle histology in cases of Cushing's and corticosteroid myopathy. However, Golding and others (1961) were able to show more striking changes on electron microscopy in five cases of corticosteroid myopathy, consisting of loss of myofilaments with fragmentation, enlarged mitochondria, and disruption of the sarcoplasmic reticulum, but they considered that these changes may not be specific.

\section{Summary}

(1) A correlated electromyographic and histological study was made of 34 cases of classical rheumatoid arthritis to determine the incidence of polymyositis.

(2) No specific abnormality was detected in eighteen cases not on corticosteroid therapy, suggesting that polymyositis is an unusual complication.

(3) Of sixteen cases on moderate corticosteroid therapy, nine showed the electromyographic features of myopathy and in two the changes developed during treatment. The implications of this are discussed.

(4) A new muscle biopsy technique, suitable for use on out-patients, is described. Approximately 60 per cent. of cases showed evidence of nodular 
myositis, but these changes were not specific and did not correlate with the electromyographic findings.

This work was performed during the tenure of a Medical Research Council fellowship which is gratefully acknowledged. I am indebted to Prof. E. G. L. Bywaters and the physicians of the Hammersmith Hospital for allowing me to study their patients and to Mr. M. Curwen of St. Bartholomew's Hospital for statistical advice.

\section{REFERENCES}

Amick, L. D. (1960). Arthr. and Rheum., 3, 54.

Bauwens, P. (1962). In "Electrodiagnosis and Electromyography", 2nd ed., ed. S. Licht, chap. 7. E. Licht, Baltimore.

Buchthal, F., and Pinelli, P. (1953). Neurology (Minneap.), 3, 424.

Guld, C., and Rosenfalck, P. (1954). Acta physiol. scand., 32, 200.

Cushing, H. (1932). Bull. Johns Hopk. Hosp., 50, 137.

Deeley, T. J. (1960). Acta Un. int. Cancr., 16, 338.

Ellis, J. T. (1956). Amer. J. Path., 32, 993.

Golding, D. N., Murray, S. M., Pearce, G. W., and Thompson, M. (1961). Ann. phys. Med., 6, 171.

Gradual, H., and Hvid, N. (1959). Acta rheum. scand., $5,34$.

Harman, J. B. (1959). Lancet, 1, 887.

Kendall, P. H. (1962). Personal communication.

and Hart, M. F. (1959). Brit. med. J., 1, 682.

MacLean, K., and Schurr, P. H. (1959). Lancet, $1,701$.

Moritz, U. (1961). Proc. X Int. Congr. Rheum., vol. 2, p. 224.

Morrison, L. R., Short, C. L., Ludwig, A. O., and Schwab, R. S. (1947). Amer. J. med. Sci., 214, 33.

Mueller, E. E., and Mead, S. (1952). Amer. J. phys. Med., 31, 67.

Müller, R., and Kugelberg, E. (1959). J. Neurol. Neurosurg. Psychiat., 22, 314.

Perkoff, G. T., Silber, R., Tyler, F. H., Cartwright, G. E., and Wintrobe, M. M. (1959). Amer. J. Med., 26, 891.

Richardson, A. T. (1956). Proc. roy. Soc. Med., 49, 111.

Ropes, M. W., Bennett, G. A., Cobb, S., Jacox, R., and Jessar, R. A. (1959). Ann. rheum. Dis., 18, 49.

Sokoloff, L., Wilens, S. L., and Bunim, J. J. (1951). Amer. J. Path., 27, 157.

Steinberg, V. L., and Parry, C. B. Wynn (1961). Brit. med. J., 1, 630.
Steiner, G., Freund, H. A., Leichtentritt, B., and Maun, M. E. (1946). Amer. J. Path., 22, 103.

Walton, J. N., and Adams, R. D. (1958). "Polymyositis". Livingstone, Edinburgh.

Woolf, A. L. (1962). In "Modern Trends in Neurology", 3rd series, ed. D. Williams, p. 11. Butterworths, London.

Yates, D. A. H. (1963). J. Neurol. Neurosurg. Psychiat., 26, 458 .

\section{Altérations musculaires dans l'arthrite rhumatismale}

\section{RÉSUMÉ}

1. On procéda à des études électromyographiques et histologiques corrélatives dans 34 cas d'arthrite rhumatismale classique pour déterminer la fréquence de la polymyosite.

2. On ne décéla pas d'anomalies spécifiques dans 18 cas qui n'étaient pas traités par des corticostéroïdes, ce qui indique que la polymyosite est une complication rare.

3. Parmi 16 cas soumis à une thérapie corticostéroïde modérée, il y en avait 9 qui acusaient des caractères électromyographiques de myopathie et dans deux d'entre eux ces caractères apparurent pendant le traitement. On discute les implications de ces faits.

4. On décrit un nouveau procédé de biopsie musculaire, d'emploi pratique dans le dispensaire. A peu près $60 \%$ des cas accusaient des signes de myosite nodulaire, mais ces altérations n'étaient pas spécifiques et ne correspondaient pas aux résultats électromyographiques.

\section{Alteraciones musculares en la artritis reumatoide}

\section{SUMARIO}

1. Resultados electromiográficos e histológicos fueron correlatados y estudiados en 34 casos de artritis reumatoide clásica para determinar la frecuencia de polimiositis.

2. No se encontraron anomalías específicas en 18 casos que no recibieron terapia corticosteroide, lo que indica que la polimiositis es una complicación poco frecuente.

3. Entre 16 casos recibiendo terapia corticosteroide moderada, se encontraron nueve con rasgos electromiográficos de miopatía y en dos de ellos estos rasgos aparecieron durante el tratamiento. Se discuten las implicaciones de estos hechos.

4. Se describe un nuevo procedimiento de biopsia muscular, de uso conveniente en pacientes ambulantes. Cerca de un $60 \%$ de los casos acusaron signos de miositis nodular, pero estas alteraciones no fueron especificas y no correspondieron a los resultados electromiográficos. 